\title{
COLLABORATION AND OUTREACH TOWARDS USE OF GEOSPATIAL TECHNOLOGIES IN INDIA WITH AN EMPHASIS ON ISRO'S EFFORT
}

\author{
Sujata Ghosh ${ }^{1,}$, Ashish Sachan ${ }^{1}$, G. Srinivas ${ }^{1}$ \\ Advanced Data Processing Research Institute, Secunderabad, India - sujata@adrin.res.in
}

\author{
Commission V, WG V/2
}

KEY WORDS: Geo-spatial technology, outreach, collaboration, ISRO, projects, policy, E-learning, content

\begin{abstract}
:
Geospatial technology is adopted in India through 'Digital India', for better governance and socio-economic benefits of common citizens. Remote sensing imageries and derived products are a direct input for geospatial data generation, monitoring resources and providing citizen services. As Indian Space Research Organisation (ISRO) is responsible for technology development, launch and data distribution of Indian remote sensing satellites, there is a conscious effort for partnership development with international space agencies and Indian industries to fulfil this requirement. Simultaneously ISRO's co-operation with government departments for geo-spatial data generation and utilization is taken as a priority. This Paper presents the effort of ISRO for cooperation with International and national agencies as well as with government departments and policy makers. In this surge of utilization of geo-spatial techniques capacity building has become very relevant. A glimpse of geospatial education through government \& academic institutes in India and Elearning is presented here with an emphasis of ISRO's contribution.
\end{abstract}

\section{INTRODUCTION}

'Digital India', driven by Geo-spatial Technology, have influenced the map to be evolved from a 'product' to 'large-scale service for societal benefit'. Decision makers' preference for quantitative and comprehensive map revolving around socio demographic data, leads to emergence of decision-maps. Remote sensing imageries and derived products are a direct input for geospatial data generation, monitoring resources and providing citizen services. Indian Space Research Organization (ISRO), having a major role to technological development and launching Indian remote sensing satellites, is responsible for remote sensing data distribution in India. With the increasing use of space based data/ information, there is a conscious effort of ISRO for partnership development through collaboration and cooperation with international/ national agencies, government departments and policy makers. This Paper present a glance on its collaboration and outreach effort for development of space technology and utilization of space based remote sensing data along with capacity building.

\section{GEOSPATIAL TECHNOLOGY OUTREACH}

Geospatial technology is being implemented to promote improved coordination for development and providing citizen services in India with associated spatial reasoning and sharing across multiple levels. 'Geo' data generation of resources, assets, infrastructures and citizens with time scale using multisensor earth observation data and its near real time utilization is taken as a priority. An overview of Indian scenario of translating geospatial technology for societal benefit is mentioned below.

\subsection{Flagship Projects for Development \& Citizen Services} several flagship projects and support programs have been identified for cooperation of ISRO and central /state government ministries by utilizing space based data and geo-spatial technology for rural and tribal development, natural resources management, energy, infrastructure, communication \& navigation, e-governance, disaster \& early warning etc. National Remote Sensing Centre (NRSC) of ISRO has developed a webbased portal 'Bhuvan' with customized analysis tools/ techniques, which serves as an interface for visualization, mapping, monitoring, platform for building user applications, evaluating, decision making and data sharing (bhuvan.nrsc.gov.in/bhuvan_links.php) through ministry/ task specific modules. Geospatial data is generated using high resolution satellite data products in synchronization with ground data \& photographs collection using customized mobile based applications. These flagship projects are coordinated, monitored and implemented by central/ state departments officials/staffs from concerned departments/ respective states along with ISRO scientists. Brief overview about different projects along with its major geospatial components and societal benefits, are compiled (Table 1-5) from different sources (Rajeswari et al, 2017, Sonal et al, 2016, NRSC and Bhuvan websites).

Projects related to urban development are implemented for mapping urban areas, smart cities development and infrastructure development (Table-1).

\begin{tabular}{|c|c|c|}
\hline Purpose & Tasks & Benefits \\
\hline \multicolumn{3}{|c|}{$\begin{array}{l}\text { Pradhan Mantri Awas Yojana (by ISRO and Ministry of Housing } \\
\text { and urban poverty) }\end{array}$} \\
\hline $\begin{array}{l}\text { Assistance to } \\
\text { urban } \\
\text { implementing } \\
\text { agencies }\end{array}$ & $\begin{array}{l}\text { - Rehabilitation of existing } \\
\text { slum dwellers } \\
\text { - Monitoring progress of } \\
\text { construction of beneficiary's } \\
\text { house by geo-tagging }\end{array}$ & $\begin{array}{l}\text { Credit link } \\
\text { subsidy for } \\
\text { beneficiary } \\
\text { for individual } \\
\text { house } \\
\text { construction }\end{array}$ \\
\hline \multicolumn{3}{|c|}{$\begin{array}{l}\text { Atal Mission for rejuvenation and urban transformation ((by } \\
\text { ISRO and Ministry of Urban development/ Town Planning) }\end{array}$} \\
\hline $\begin{array}{l}\text { GIS based } \\
\text { Master plan } \\
\text { development } \\
\text { of } 500 \text { cities } \\
(1: 4000) \text { for } \\
\text { policy making }\end{array}$ & $\begin{array}{l}\text { - Geospatial database of } \\
\text { basemaps, landuse and } \\
\text { ground data creation } \\
\text { - Thematic \& policy maps } \\
\text { with identification of issues } \\
\text { \& demand assessment }\end{array}$ & $\begin{array}{l}\text { Providing } \\
\text { water, } \\
\text { sanitation and } \\
\text { amenities } \\
\text { with capacity } \\
\text { building }\end{array}$ \\
\hline
\end{tabular}

Table-1. Projects related to urban development

\footnotetext{
${ }^{*}$ Corresponding author
} 
Projects related to Rural development aims at generating employment and socio-economic development of the area by creating/ monitoring infrastructures \& assets in rural area of India and providing services for amenities (Table-1).

\begin{tabular}{|c|c|c|}
\hline & Tasso & \\
\hline \multicolumn{3}{|c|}{$\begin{array}{l}\text { Monitoring Rural development Program by (ISRO and Ministry } \\
\text { of Rural Development) (implementing Pradhan Mantri Gram } \\
\text { Sadak Yojna, MNREGA, Indira Awas Yojna etc) }\end{array}$} \\
\hline \multirow{5}{*}{$\begin{array}{l}\text { Evaluate and } \\
\text { monitoring } \\
\text { the progress } \\
\text { of flagship } \\
\text { govt projects } \\
\text { (like } \\
\text { MNREGA } \\
\text { for rural } \\
\text { employ-ment } \\
\text { and } \\
\text { infrastrucre } \\
\text { creation) } \\
\text { through state } \\
\text { governments } \\
\text { and provide } \\
\text { basic } \\
\text { services. }\end{array}$} & $\begin{array}{l}\text { - Geospatial database on } \\
\text { MNREGA with } 256 \text { rural } \\
\text { asset mapping \& Mobile } \\
\text { applications }\end{array}$ & $\begin{array}{l}\text { - Identifying } \\
\text { areas with a } \\
\text { scope of work } \\
\text { generation }\end{array}$ \\
\hline & $\begin{array}{l}\text { on of rural roads } \\
\text { ts to ensure all } \\
\text { anectivity }\end{array}$ & $\begin{array}{l}\text { ring \& } \\
\text { tion of } \\
\text { ig }\end{array}$ \\
\hline & $\begin{array}{l}\text { ging and time } \\
\text { g of stages of } \\
\text { ment. }\end{array}$ & $\begin{array}{l}\text { activity (used } \\
\text { by AP State } \\
\text { Housing } \\
\text { Corp) }\end{array}$ \\
\hline & $\begin{array}{l}\text { rural } \\
\text { ting up an } \\
\text { agged pho }\end{array}$ & $\begin{array}{l}\text { - Used for } \\
\text { approvals of } \\
\text { final fund } \\
\text { allocation in }\end{array}$ \\
\hline & $\begin{array}{l}\text { oad request } \\
\text { lon to co }\end{array}$ & \\
\hline \multicolumn{3}{|c|}{$\begin{array}{l}\text { Space based Information Support for Decentralized Planning } \\
\text { (by ISRO-Ministry of Panchayati Raj) }\end{array}$} \\
\hline $\begin{array}{l}\text { Panch } \\
\text { Institl } \\
\text { track }\end{array}$ & & $\begin{array}{l}\text { Capacity } \\
\text { building of } \\
\text { stake holders }\end{array}$ \\
\hline $\begin{array}{l}\text { of } 280 \\
\text { panchayat } \\
\text { assets }\end{array}$ & $\begin{array}{l}\text { at panchayat level with } \\
\text { State-wise } \\
(1: 10,000)\end{array}$ & COM \\
\hline \multicolumn{3}{|c|}{$\begin{array}{l}\text { Tribal development program (by ISRO and Ministry of Tribal } \\
\text { Affair) in synchronization with MNREGA. }\end{array}$} \\
\hline $\begin{array}{l}\text { Socio- } \\
\text { economic } \\
\text { development } \\
\text { by supporting } \\
\text { fisheries for } \\
\text { areas with } 25 \\
\% \text { of tribal } \\
\text { population }\end{array}$ & $\begin{array}{l}\text { Identifying existing water } \\
\text { collection spots, potential } \\
\text { for fish culture } \\
\text { GIS database of potential } \\
\text { fish-breeding ponds with } \\
\text { time series mapping } \\
\text { (Geopdf products) }\end{array}$ & $\begin{array}{l}\text { - Tribal } \\
\text { dominated } \\
\text { districts in } 24 \\
\text { states /UTs } \\
\text { - Capacity } \\
\text { building of } \\
\text { state officials }\end{array}$ \\
\hline
\end{tabular}

Table-1. Projects related to rural development

Bhuvan panchayat and Bhuvan MNREGA (Fig-1) support rural development with participation of local residents.

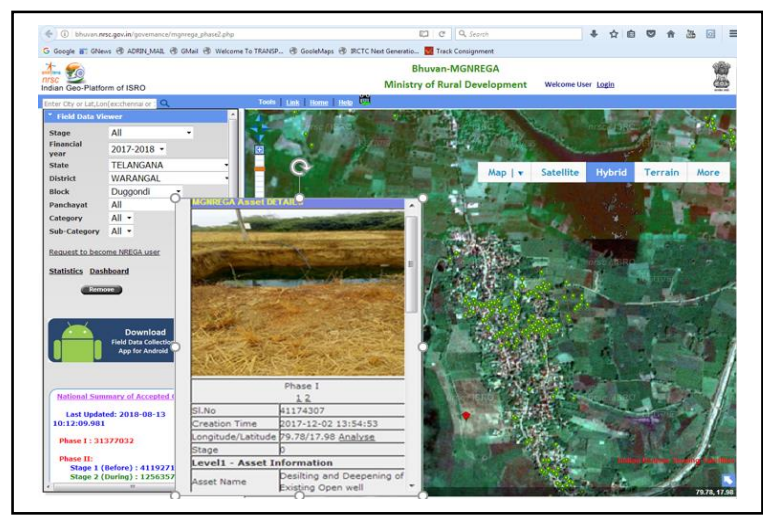

Fig-1: Bhuvan MNREGA Application
Programs linked with agricultural development oriented towards watershed based development for crop irrigation, soil and water conservation (Table-3).

\begin{tabular}{|c|c|c|}
\hline Purpose & Tasks & Benefits \\
\hline \multicolumn{3}{|c|}{$\begin{array}{l}\text { Integrated watershed Management Plan (by ISRO and Ministry } \\
\text { of Rural Development }\end{array}$} \\
\hline $\begin{array}{l}\text { Soil and water } \\
\text { conservation } \\
\text { and assured } \\
\text { crop irrigation }\end{array}$ & $\begin{array}{l}\text { - Identifying sites of water } \\
\text { resources harvesting, } \\
\text { building check dams, } \\
\text { desilting of tanks and other } \\
\text { watershed activities using } \\
\text { geospatial technology } \\
\text { - Monitoring the development }\end{array}$ & $\begin{array}{l}\text { - Employment } \\
\text { under } \\
\text { MNREGA in } \\
\text { more than } \\
5000 \text { micro- } \\
\text { watersheds in } \\
10 \text { states }\end{array}$ \\
\hline \multicolumn{3}{|c|}{$\begin{array}{l}\text { Accelerated Irrigation Benefit Program (by ISRO-Ministry of } \\
\text { water Resources \& CWC) }\end{array}$} \\
\hline $\begin{array}{l}\text { Implementing } \\
\text { and Online } \\
\text { monitoring of } \\
>140 \text { ongoing } \\
\text { irrigation } \\
\text { projects (pre } \\
\text { and post } \\
\text { monsoon) }\end{array}$ & $\begin{array}{l}\text { - Generating inventory of } \\
\text { existing irrigation } \\
\text { infrastructure and assess } \\
\text { critical gaps. } \\
\text { - Used in critical project } \\
\text { review for funding by CWC }\end{array}$ & \begin{tabular}{|l|} 
Reconcile \\
irrigation \\
potential \\
reported by \\
state govt
\end{tabular} \\
\hline \multicolumn{3}{|c|}{$\begin{array}{l}\text { Coordinated program on Horticulture Assessment and } \\
\text { Management using geo-information (by ISRO and Ministry of } \\
\text { Agriculture) }\end{array}$} \\
\hline $\begin{array}{l}\text { Assessment \& } \\
\text { inventory of } \\
\text { horticultural } \\
\text { crops }\end{array}$ & $\begin{array}{l}\text { - Assess site-suitability for } \\
\text { expansion of plantation } \\
\text { - Infrastructure planning to } \\
\text { minimize losses of fruits/ } \\
\text { vegetables }\end{array}$ & $\begin{array}{ll}- \text { Pilot phase } \\
\text { for } 7 \text { crops } \\
\text { covering } 11 \\
\text { states }\end{array}$ \\
\hline
\end{tabular}

Table-3. Projects related to development of natural resources

Projects related to natural/ cultural resource conservation will help in restoration / conservation and management of national resources in a better way (Table-4).

\begin{tabular}{|c|c|c|}
\hline Purpose & Tasks & Benefits \\
\hline \multicolumn{3}{|c|}{$\begin{array}{l}\text { Conservation of World Heritage sites, ancient monuments and } \\
\text { archeological sites (by ISRO and Ministry of Culture) }\end{array}$} \\
\hline $\begin{array}{l}\text { Development, } \\
\text { monitoring \& } \\
\text { conservation of } \\
\text { heritage sites } \\
\text { with site } \\
\text { management } \\
\text { plan and assess } \\
\text { vulnerability }\end{array}$ & $\begin{array}{l}\text { - Database Inventory of } \\
\text { heritage sites \& monuments } \\
\text { to identify vulnerability } \\
\text { - Demarcate zones of } \\
\text { prohibited/ regulated area } \\
\text { and Database integration } \\
\text { with National Monument } \\
\text { authority }\end{array}$ & $\begin{array}{l}- \text { Promotion of } \\
\text { tourism and } \\
\text { Mitigate } \\
\text { changes in } \\
\text { heritage sites } \\
\text { - Plan for } 3,600 \\
\text { heritage sites }\end{array}$ \\
\hline \multicolumn{3}{|c|}{ Program by ISRO and National mission for clean Ganga } \\
\hline $\begin{array}{l}\text { Action plan for } \\
\text { Clean Ganga } \\
\text { Mission and } \\
\text { planning tool } \\
\text { to support and } \\
\text { decision } \\
\text { making }\end{array}$ & $\begin{array}{l}\text { - Utilizing geospatial and } \\
\text { crowd sourcing (mobile } \\
\text { App) to enable community } \\
\text { participation (collect/report } \\
\text { on pollution sources) } \\
\text { - Total suspended sediments } \\
\text { and turbidity mapped for } \\
600 \mathrm{~km}\end{array}$ & $\begin{array}{l}\text { Effective } \\
\text { monitoring } \\
\text { and timely } \\
\text { interventions } \\
\text { to maintain } \\
\text { Ganga water } \\
\text { quality }\end{array}$ \\
\hline
\end{tabular}

Table-4. Programs related to development of natural resources

Programs linked with citizen services are oriented towards identifying gap areas and providing ease of service (Table-5). Recent thrust towards digital India and digital economy has surged the demand of satellite internet services (Fig-5).

\begin{tabular}{|l|l|l|}
\hline Purpose & Tasks & Benefits \\
\hline $\begin{array}{l}\text { Automated Warnings at Unmanned Level Crossings by ISRO and } \\
\text { Indian railways. }\end{array}$ \\
\hline
\end{tabular}




\begin{tabular}{|c|c|c|}
\hline $\begin{array}{l}\text { Using } \\
\text { SATCOM \& } \\
\text { Navigation } \\
\text { Services }\end{array}$ & $\begin{array}{l}\text { - Geospatial database of } \\
\text { unmanned level crossings } \\
\text { - GAGAN Rail navigator } \\
\text { mounted on train. }\end{array}$ & $\begin{array}{l}\text { Automatic } \\
\text { activation of } \\
\text { distance based } \\
\text { train hooter. Pilot } \\
\text { studies completed } \\
\end{array}$ \\
\hline \multicolumn{3}{|c|}{$\begin{array}{l}\text { Paperless Tickets for Mumbai Suburban Railway (by ISRO and } \\
\text { Western Railway) }\end{array}$} \\
\hline $\begin{array}{l}\text { Mobile app } \\
\text { for ticket } \\
\text { booking } \\
\text { through Geo- } \\
\text { fencing }\end{array}$ & $\begin{array}{l}\text { through } \\
\text { nmuter's } \\
\text { and } 2 \mathrm{~km} \\
\text { n outer }\end{array}$ & $\begin{array}{lr}\text { Pilot } & \text { project } \\
\text { covers } 135 \mathrm{~km} \\
\text { Church gate- } \\
\text { Dahanu section }\end{array}$ \\
\hline \multicolumn{3}{|c|}{ Data Connectivity for Rural India } \\
\hline $\begin{array}{l}\text { Monitoring } \\
\text { rural roads } \\
\text { construction }\end{array}$ & $\begin{array}{l}\text { Rea } \\
\text { the } \\
\text { prov }\end{array}$ & $1 \mathrm{a}$ \\
\hline \multicolumn{3}{|c|}{$\begin{array}{l}\text { Geo-spatial inventory of Post offices (by ISRO and Ministry of } \\
\text { Communication) }\end{array}$} \\
\hline $\begin{array}{lr}\text { Identify } & \text { gap } \\
\text { areas } & \text { and } \\
\text { planning } & \text { for } \\
\text { services } & \text { and } \\
\text { new } & \text { post } \\
\text { offices. } & \end{array}$ & $\begin{array}{l}\text { - Geo-spatial d } \\
\text { mobile appl } \\
\text { web based i } \\
\text { geotagging p }\end{array}$ & $\begin{array}{l}\text { ations to } \\
\text { nearest PO } \\
\text { ortest route } \\
\text { Pilot studies }\end{array}$ \\
\hline
\end{tabular}

Table-5. Programs to provide citizen services

Most of these services are provided by citizen centric customized mobile applications. The implementation of these projects will create more transparent, efficient and scalable approaches to delivering services to citizens and government interdepartmental interactions.

\subsection{Weakness and Issues of Geospatial Outreach in India}

Along with the advantages and potentials of geospatial technologies, the biggest challenges are data sharing linked with necessary data security framework, data policies and Trained human resources.

Data Sharing: Structured geospatial data on the basis of the Indian administrative structure are created earlier by NRDMS, NRIS and National Spatial Data Infrastructure geo-portal (by DOS and DST). Apart from this different departments and states have set up individual portals (like NRSC, Survey of India, NIC, Census of India, Geological Survey of India, MoES, Telangana Govt, AP govt etc have their own platform/ portal). NSDI established of core metadata standards but thematic standards are varying among different data of different agencies. National GIS (NGIS), by DST, has integrated geo-spatial data available with organisations like Survey of India, National Informatics Centre, National remote sensing center \& Ministry of Earth Sciences provide data \& development support services for state government departments. Digital India Program took over few years back with an orientation towards e-governance applications and various mission mode projects. National Centre of Geo-informatics (NCOG) is set up to take to care of geospatial resources, applications and solutions to human resources development, collaboration with public and private agencies and R\&D. Issues about data sharing, standardization of data at structural and thematic level may get resolved with widespread data uses and sharing.

Data Policies: In India till now the right to generate authenticated geospatial data is with government institutes and agencies. As the data is with spatially referenced context (maps, imagery, point information by GPS and other means), its generation and access is controlled by the state through established policies. These policies effectively control and regulate the use of Indian geospatial data by Indian users.

- Space based Remote Sensing Data Policy - Data is generated and distributed by the Dept of Space. It regulates access to data with better than $1 \mathrm{~m}$ resolution. Purchase of such Indian and foreign data are subject to screening and is purchased from/ through NRSC. Public sector units need a govt certificate to access sub meter data, with a declaration of data use for development purpose in India. Antrix, commercial arm of ISRO, enters into agreements with foreign entities for launches from other countries, to access Indian satellite data, for supplying/ marketing their data etc.

- Map Policy - Topographic data is generated, modified distributed and regulated the access by Survey of India. Topomaps and Open series maps (OSM), available to general users (except international boundaries) without height information

- Aerial surveys, including those using Unmanned Aerial Vehicles, are regulated by the Director General of Civil Aviation (DGCA), the Ministries of Defence and Home Affairs

- Geospatial Information Regulation Bill (by Ministry of home affairs) and a new Geospatial Data Policy (by DST) is released at 2016. It is expected to addresses the requirements of Indian users in the government, industry, education sectors.

- Recent surge in demand for UAV/ drone surveying and photography from many agencies including government, academic and industry triggers the release of a new UAV policy (2018). It indicates DGCA to issue permission in sync with other agencies for flying the platform over a particular region with clause of a post flight data review. Permission for the devices and sensors to be mounted on the platform is covered in another Policy issued by MOD dated earlier (Padhi et al, 2018). A unified geo-data policy may help which will satisfy development and civilian applications with taking care of national security concern.

\section{SPACE TECHNOLOGY COLLABORATION}

Since international and strategic relations are built on political, economic and cultural aspects along with scientific and technological factors, 'Space' forms a trans-national dimension for international cooperation and goodwill generation. Effective and appropriate national, International collaborations, which may happen in Governmental, non-governmental, Commercial, bilateral, regional, multilateral and Global level are an integral part for development of space technology, remote sensing data generation, and its applications.

\subsection{Collaboration of ISRO with international community}

Effective and appropriate collaborations in areas of space launch platforms \& satellite missions, sensor developments, extra planetary mission, telemetry tracking \& space communication, earth observation data exchange, data reception/distribution, capacity building and participation in global initiatives makes a huge impact. Most common international space agreements are relating to tracking facilities and data distributions.

ISRO has formal agreements/ MOUs with many nations/organizations for collaborative launches, joint scientific and technological activities, tracking facilities activities (restricted ground involvements) and data distributions. Some of ISRO's international collaborations with respective components/ services (Table-6 and following sub-sections) are mentioned: 


\begin{tabular}{|c|c|c|c|}
\hline $\begin{array}{l}\text { Technology } \\
\text { / Element }\end{array}$ & $\begin{array}{l}\text { Mission } \\
\text { /technology }\end{array}$ & $\begin{array}{l}\text { Components } \\
\text { /Criticality }\end{array}$ & Country \\
\hline \multirow{2}{*}{$\begin{array}{l}\text { Heavy lift } \\
\text { vehicle } \\
\text { Launch } \\
\text { service }\end{array}$} & $\begin{array}{l}\text { For } 18 \text { Geo- } \\
\text { stationary } \\
\text { Indian satellites }\end{array}$ & Ariane & France \\
\hline & GLONASS-M & GSLV & Russia \\
\hline $\begin{array}{l}\text { South Asian } \\
\text { satellite }\end{array}$ & $\begin{array}{l}\text { Meteorological } \\
\text { sensors \& } \\
\text { transponders }\end{array}$ & $\begin{array}{l}\text { GSLV, GSAT- } \\
9 \text {, Sensors. Data } \\
\text { reception }\end{array}$ & $\begin{array}{l}\text { South } \\
\text { Asian } \\
\text { countries }\end{array}$ \\
\hline \multirow{5}{*}{$\begin{array}{l}\text { Launch } \\
\text { platform/ } \\
\text { Launch } \\
\text { Service }\end{array}$} & SPOT 6 \& 7 & \multirow{5}{*}{$\begin{array}{l}\text { PSLV } \\
\text { Launch service } \\
\text { for LEO/ } \\
\text { Remote } \\
\text { Sensing/ Nano } \\
\text { satellites }\end{array}$} & France \\
\hline & TECSAR & & Israel \\
\hline & $\begin{array}{l}\text { Astrium small } \\
\text { satellites }\end{array}$ & & Europe \\
\hline & $\begin{array}{l}\text { Cubesat } \\
\text { ASSAT } 1 \& 2 \\
\text { Nano satellites }\end{array}$ & & $\begin{array}{l}\text { Taiwan } \\
\text { Norway }\end{array}$ \\
\hline & Youthsat & & Russia \\
\hline \multirow{3}{*}{$\begin{array}{l}\text { Launch } \\
\text { Service by } \\
\text { PSLV, } \\
\text { Sensors } \\
\text { jointly } \\
\text { developed }\end{array}$} & $\begin{array}{l}\text { Megha } \\
\text { Trophiques }\end{array}$ & $\begin{array}{l}\text { Scarab, Saphir, } \\
\text { Madras }\end{array}$ & France \\
\hline & SARAL & Altika, Argos & France \\
\hline & NISAR & $\begin{array}{l}\text { L \& S band } \\
\text { SAR sensor }\end{array}$ & USA \\
\hline \multirow{6}{*}{$\begin{array}{l}\text { Science } \\
\text { Payload } \\
\text { cooperation }\end{array}$} & Mars Mission & Science payload & USA \\
\hline & Chandrayaan-1 & $\begin{array}{l}\text { Spectrometer, } \\
\text { SIR-2, SARA, } \\
\text { Radome, } \\
\text { MiniSAR, M3 }\end{array}$ & $\begin{array}{l}\text { ESA } \\
\text { USA }\end{array}$ \\
\hline & Astrosat & $\begin{array}{l}\text { Ultraviolet } \\
\text { imaging } \\
\text { telescope }\end{array}$ & Canada \\
\hline & Oceansat-2 & ROSA & Italy \\
\hline & Coronas Photon & $\begin{array}{l}\text { X-ray } \\
\text { Astronomy } \\
\text { Instrument }\end{array}$ & India \\
\hline & Sensor & $\begin{array}{l}\text { Space X-ray } \\
\text { instrument }\end{array}$ & Japan \\
\hline \multirow[t]{3}{*}{ Engines } & $\begin{array}{l}\text { Cryogenic } \\
\text { Engine }\end{array}$ & $\begin{array}{l}\text { KVD-1 (GSLV } \\
\text { upper stage) }\end{array}$ & \\
\hline & $\begin{array}{l}\text { Liquid engine } \\
\text { Technology }\end{array}$ & PSLV $2^{\text {nd }}$ stage & France \\
\hline & $\begin{array}{l}\text { Electric ion } \\
\text { propulsion } \\
\text { Engine (EIP), }\end{array}$ & $\begin{array}{l}\text { For SAARC } \\
\text { satellite }\end{array}$ & Japan \\
\hline \multirow[t]{5}{*}{$\begin{array}{l}\text { Telemetry } \\
\text { tracking and } \\
\text { Navigation }\end{array}$} & $\begin{array}{l}\text { Mars Mission } \\
\text { launch } \\
\text { monitoring }\end{array}$ & $\begin{array}{l}\text { Deep space } \\
\text { network }\end{array}$ & USA \\
\hline & Chandrayaan1 & \multirow{2}{*}{$\begin{array}{l}\text { Ground-station, } \\
\text { Antenna, Signal }\end{array}$} & \multirow[t]{2}{*}{ Russia } \\
\hline & GLONASS & & \\
\hline & $\begin{array}{l}\text { Ground station/ } \\
\text { data reception }\end{array}$ & $\begin{array}{l}\text { Various Indian } \\
\text { Missions }\end{array}$ & $\begin{array}{l}\text { Brunei, } \\
\text { Indones } \\
\text {-ia } \\
\end{array}$ \\
\hline & BRICKS & Earth station & Brazil \\
\hline
\end{tabular}

Table-6: ISRO's International cooperation compiled from different sources

Green color indicated technology/ services are provided by ISRO; Blue color indicated that ISRO received cooperation from international agencies/ communities; Light Pink color indicate launch vehicle (short term cooperation): Orange color indicate technical co-operation; Violet color indicate ground segment service linked with infrastructure and/ or technological expertise; Grey color indicate scientific cooperation and science instrument contribution (short term collaboration); Cyan color indicates joint development, Yellow color indicates sensor mission element development jointly with launch support from ISRO (Long term collaboration); Peach color indicate satellite built, launch, data distribution and capacity building by India

\subsection{Participation in Space Forums/ Community}

ISRO is participating actively in International space forums like CEOS, GEOS, ISPRS, APRSAF, UN-ESCAP to reap the benefit of space technology. Under these umbrellas it is involved in forest carbon tracking, global agricultural monitoring initiative, Global forest observation initiative by providing data or geophysical products. Data sharing of Indian satellites by ISRO is playing a prominent role in following areas-

- Under Sentinel Asia initiative applying remote sensing and Web-GIS technologies to support disaster management in the Asia-Pacific region.

- Megha-Trophiques data from ROSA and SAFIR sensor are processed and shared with international service users for study of the tropical atmosphere conditions and precipitation.

- Saral (Altika and Argos) data is shared with international community for studying ocean altimetry.

- Oceansat-2 scatterometer derived information are distributed globally in near-real time for Ocean surface vector wind through an arrangement with Eumetsat.

- Under UN-ESCAP program, India is providing technical support for development of Draught monitoring system of Srilanka, using satellite data with field data collection and data viewing at Bhuvan.

ISRO in coordination with CSSTEAP at Dehradun supports capacity building to neighbouring nations through different course module on Remote sensing, data processing, GIS and theme based applications. A comprehensive program is initiated on capacity building on small satellites technology for developing countris.

\subsection{Collaboration of ISRO with Public Sector in India}

ISRO is considered as one of the leaders in developing space based societal applications. Outcomes of space research and programs are perceived many times directly in terms of 'Money spent vs gained'. It infers the requirement of satellite launch to meet national requirement of geospatial data for different applications, providing critical communication bands and commercial satellite launches etc., which has a direct impact on economy. Indirect benefits are linked with creating technological capacity, International collaboration and diplomacy, natural resource management, generation of employment education and overall development of society. ISRO has taken initiatives for collaboration and technology transfer with Indian Small and Medium-Scale Enterprises with a buy back incentive to converting a supplier enterprise to vendor in areas of space transportation, spacecraft development and ground operations functions. Industry may be partners in Systems Assembly, Integration and Testing (AIT) of Indian satellites in due course. There is a formation of a consortium of industries with ISRO for the development of Polar Satellite Launch Vehicle (PSLV). This may help to achieve satellite launch volumes for meeting local and international demand (Dasgupta et al, 2017). Increased annual launch frequencies in next few years lead to emergence of different industry-government collaboration models with use of existing ISRO and industry infrastructure, for further capacity building in the industry. 


\section{CAPACITY BUILDING IN GEOSPATIAL TECHNOLOGY}

A National taskforce on Geospatial education (created by Ministry of Human Resources) have identified 3 types of workforce requirement in its report (2013) for implementing geospatial technology. The categories are - a) Skilled workforce in a large number for data creation, mapping, GIS operators, ground data collection (consumer of geospatial technology), b) Technical professional having specific training and knowledge for particular tasks like data processing, Geodatabase, GIS analysis etc. (consumer and developer of geospatial technology) c) Experts with geospatial degree, capable of handling geospatial projects independently (developer of geospatial technology).In India though the capacity building efforts started long back, it has picked up the momentum in last decades.

\subsection{On-campus Education through Institutes}

Capacity building in geospatial technology in India is catered by government institutes like Indian Institute of remote sensing (IIRS), National remote sensing Centre (NRSC), Survey of India (SOI), Geological Survey of India (GSI), the Forest Survey of India (FSI), and Departments of Land Records in different states since past three decades. These organizations have updated the training courses/ facilities with new technologies to train professionals from the relevant fields in above mentioned all three categories (Long term Masters, PhD courses as well as short term capsule/ thematic module courses and workshops). NRSC and IIRS of ISRO also offers customized short term course modules for capacity building related to different projects mentioned earlier. Apart from these institutes the learning curve of geospatial technology are supported by IITs, NITs and universities at their On-campus courses. Recently commercial organizations started to provide courses online. A brief about each category is mentioned below-

a) Academic institutions and universities in India offer 2 years M.Sc, in Geomatics/ Geo-informatics and one year PG diploma course for Masters students. Technical institutes like IITs and NITs (some of them) have 4 year B.Tech in geospatial technology or Geospatial Engineering courses and 2 years M.Tech courses in Geomatics/ Geo-informatics. Indian Institute of Space technology (IIST) offer 4 years B. Tech courses related to Space technology, Avionics and Remote sensing. Many institutes also offer a short module as part of its civil engineering, geo-engineering and mining, Hydrology, earth science, regional planning and architecture curriculum in a limited way.

b) Academic research plays a very important role in developing a strong foundation for scientific development and patenting in relevant fields. ISRO encourages academic research via its RESPOND (Research Sponsored) program. Premiere academic institutions, including IISc, IITs, NITs, universities receive funding to conduct research related to Space science and Engineering, Geospatial technology and its different applications. DST also offers limited projects for research relevant to geospatial technology. Successful outcome of these projects may lead to create innovative 'models' apart from commercialization of technologies developed.

\subsection{Geo-Spatial E-learning - Indian initiatives}

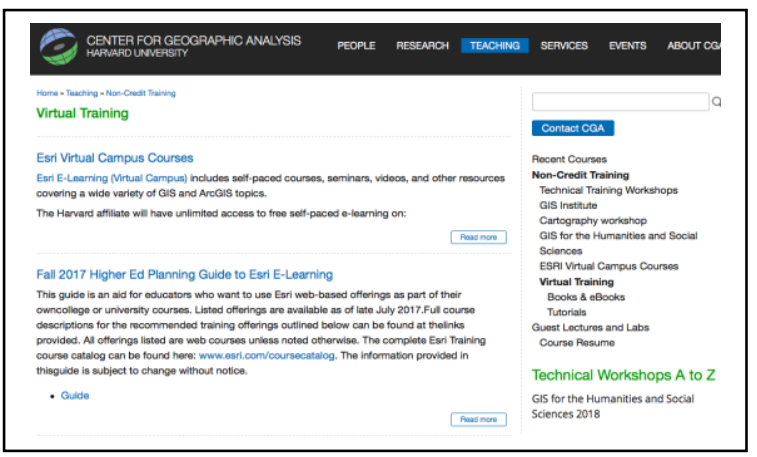

Indian higher education system is large (next to US and China) enough to support the emerging geospatial requirement, but a small percentage of higher learning educational institutes are equipped with infrastructure for collaborative/ online education in terms of infrastructure, high-speed broadband internet and quality content with Indian case studies in geospatial technology.

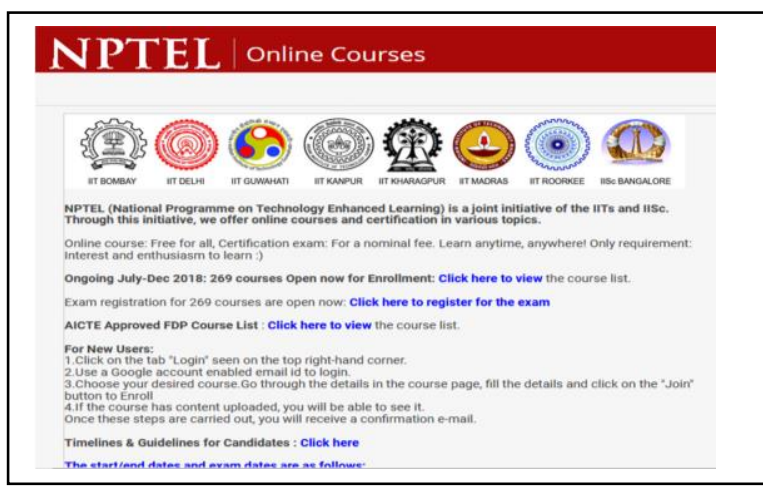

Noteworthy E-learning initiatives at India and worldwide are:

- National Program on Technology Enhanced Learning (NPTEL), a joint initiative of the IITs and IISc for creating Open Online Courses (Fig-2). As part of this few courses are provided where student can registrar and get certified in geospatial technologies.

- Free and Open Software in Education (FOSSEE), part of the National Mission on Education through Information and Communication Technology (ICT) by MHRD is enabling students to improve their computational skills by learning new free and open source tools online, but absence of internet is a major hindrance for its spread in Rural-India.

Mumbai IIT is having an outreach program to reach out beyond its student community online Continuing education programs (CEP) offers short intensive courses for the enhancement of the expertise of working professionals in industry and government. It uses different mediums and variety of technologies, (uploading web-based courses, taking video recordings of classroom lectures, and transmitting courses through internet with live interaction). Live courses (https://onlinecourses.nptel.ac.in/) are transmitted through internet, using a web interactive platform

Fig-2: NPTEL portal for E-learning

- Indian Institute of Remote Sensing (IIRS) offers online education courses in different topics related to Geospatial technology, Remote Sensing, GPS and Theme based applications. At present more than 370 universities $\backslash$ institutes have collaborated with it, having a varied student base of Masters, $\mathrm{PhD}$ students and professionals.

- E-Tutor for GIS (developed by IIT Bombay) is multimedia based installable indigenous GIS package GRAM++ provides hands on and has assisted in "GIS based technologies for local 
level planning. It is powered by application and case studies linked bibliography. texts, animations, questions base, quiz, presentation and hands-on exercise.

- Geospatial Software companies are providing demand driven online short courses and online webinar/ training along with contents based on case studies and applications. ESRI, Hexagon, e-Cognition, Envi has a very strong base of user's community, supporting learning and problem solving by sharing many applications based contents relevant to Indian context which are available at the respective website, user community links and webinar.

- E-Learning through Virtual University and Educational websites - Students and professionals learn new skills through online, real time communications within a realistic virtual environment (example- Second-Life and OpenSIM) and vitual

Fig-3 E-learning for geospatial analysis of Harvard University classrooms. Many American universities including Harvard, Texus state and Standford have set up virtual campus (Fig3).Popular educational websites like MIT Open Courseware and online platforms like edX, Coursera connect learners to the best universities with a nominal fee or freely available geospatial courses. Industry considers geospatial technologies related to IT without knowledge of geography, on the other hand students with 'geo' background is not well versed in computer applications programming, SIW and data processing. Introducing geospatial subjects in school curricula by the Central Board of Secondary Education is a good beginning in this regard.

\section{CONCLUSION}

Generation and utilization of space based geospatial data will lead to more International and national collaboration. Progress of Geospatial national projects and collaboration of government will cater geo-conscious decision makers to take better decisions and promote citizen services. Ground data collections using mobile applications, as part of different projects, will lead to have a citizen's database with GPS points, geotagged photographs for further utilization. Launch of upcoming communication satellites higher bandwidth will enable faster internet delivery at interior part of the country. Interactive Elearning Geospatial contents will be more popular with image, maps, multimedia along with Indian examples and case based scenarios will improve the effectiveness, practical hands on experience. Through outreach program at National Remote Sensing Centre and Space Application Centre students of Master and $\mathrm{PhD}$ degree are getting opportunity to contribute in national projects and gaining practical experiences. Convenient Internet delivery, greater richness of content, the availability of effective quality evaluations will ensure the expanded use of e-learning in the future.

\section{ACKNOWLEDGMENT}

The authors are thankful to S. K. Patra, P. V. Radha Devi for their suggestions. We express our gratitude to Raghu Venkatraman, Director, ADRIN for his guidance and support. The authors are also thankful to the content generator for Geospatial E-learning at numerous sites and authors of numerous open contents available online relevant to the topic.

\section{REFERENCES}

Annadurai M., 2018. New Thrust in Indian Space Programme ... A Glance, In: International technical meet on quality assurance, (www.unoosa.org/documents/pdf/copuos/stsc/2018/ tech-13E.pdf
Annadurai M., 2016. India's International Cooperation in Earth Observation Missions. In: 60th Session of UNCOPUS - Vienna (www.unoosa.org/documents/pdf/copuos/2017/ copuos2017tech33E.pdf)

Arup Dasgupta, 2017. In: Unlocking the Potential of Geospatial Data at Space India 2.0- commerce, Policy, security and Governance perspectives, edited by Rajeswari Pillai Rajagopalan, Narayan Prasad (Eds), Chapter-V, pp- 51-70 ISBN: 978-81-86818-28-2

Lau, Neil Mottinger, Brian Rush, Roby Wilson, Tung-Han You, 2015. A journey with MOM, California Institute of Technology (http://issfd.org/2015/files/downloads/papers/001_Helfrich.pdf)

Dangermond J., 2013. In: India's Geospatial Success by ArcNews Fall 2013, (http://www.esri.com/esri-news/arcnews/ fall13articles/indias-geospatial-success)

Gerhard König, 2008. Best practice in e-learning applications on photogrammetry, remote sensing and GIS, In: ISPRS Commission VI, WG VI/2, Vol. IV-1/W1, pp. 215-222.

Impact of International Cooperation for Sustaining SpaceScience Programs (https://arxiv.org/pdf/1610.08618.pdf)

Kamaljeet Singh, A. V. Nirmal, 2017. Technological advancement by bridging the gap between industry and academia, In: IEEE-MITE 2017,

Mary Fargher, 2018. WebGIS for Geography Education: Towards a Geo-Capabilities Approach, In: ISPRS International Journal of Geo-Information. Vol. 7, doi:10.3390/ijgi7030111.

Report of Sub-Committees of Task Force on Geospatial Education (2013)

R C Padhi and Arup Dasgupta, 2018. Indian Aerial Photography Policy-A Critique.

Mariana Belgiu, Josef Strobl and Gudrun Wallentin, 2015. Open Geospatial Education, In: ISPRS International Journal of GeoInformation, Vol-4, pp. 697-710. ISSN- 2220-9964 (www.mdpi.com/journal/ijgi/)

Sonal Agarwal, 2016. Bhuvan Overview and Applications ISRO Geo-Platform (http://mohua.gov.in/upload/uploadfiles/ files/Bhuvan_overview_applications-min.pdf)

Sinha K., Malik Z., Rezgui A., Fox D.L., Barnes C.G., Lin K., Heiken G., Thomas W.A., Gundersen L.C., Raskin R., Jackson I., Fox P., McGuinness D., Dogan Seber D., Zimmerman H., 2010. Geoinformatics: Transforming data to knowledge for geosciences. GSA Today, 20(12), pp. 4-10.

Stutee Gupta, Harish Karnataka, PLN Raju, 2016. GeoInformatics in India: Major Milestones and Present Scenario. In: The International Archives of the Photogrammetry, Remote Sensing and Spatial Information Sciences, XXIII ISPRS Congress Volume XLI-B6, pp. ?

Sulochana Shekhar, 2014. A study on state of geospatial courses in indian universities, In: The International Archives of the Photogrammetry, Remote Sensing and Spatial Information Sciences, Vol. XL-8, pp. 1443-1446. doi:10.5194/isprsarchivesXL-8-1443-2014 
Space Collaboration between India and France -Towards a New Era (https://www.ifri.org/sites/default/files/atoms/files av78

_lele_space_collaboration_india_france_final.pdf)

http://bhuvan.nrsc.gov.in/bhuvan_links.php

http://www.gis.harvard.edu/training/non-credit-training/virtualtraining

https://www.iirs.gov.in/IIRS-Outreach-Programme

https://www.esri.com/training/catalog/search/

https://www.geospatialworld.net/blogs/indo-russiancollaboration-glonass-navic/

www.isro.gov.in 